\title{
Ecological sustainability of rice farms in Siak District, Riau, Indonesia
}

\author{
RACHMIWATI YUSUF ${ }^{1}$, USMAN M. TANG ${ }^{2}$, RAHMAN KARNILA ${ }^{2}$, INDRA FUADI $^{3}$, USMAN PATO ${ }^{4, \bullet}$ \\ ${ }^{1}$ Riau Assessment Institute for Agricultural Technology. Jl. Kaharuddin Nasution No. 341, Pekanbaru 28284, Riau, Indonesia \\ ${ }^{2}$ Environmental Sciences Program, Universitas Riau. Jl. Cinta Raja, Sail, Pekanbaru 28127, Riau, Indonesia \\ ${ }^{3}$ Food Crops and Horticultural Protection Agency of Riau Province. Jl. Hang Tuah Ujung No. 71, Pekanbaru 28289, Riau, Indonesia \\ ${ }^{4}$ Faculty of Agriculture, Universitas Riau. J1. Subrantas Km. 12,5, Simpang Baru, Tampan, Pekanbaru 28292, Riau, Indonesia \\ Tel.: +62-8127639712, Fax.: +62-76363270, `email: usmanpato@yahoo.com
}

Manuscript received: 1 June 2020. Revision accepted: 26 July 2020.

\begin{abstract}
Yusuf R, Tang UM, Karnila R, Fuadi I, Pato U. 2020. Ecological sustainability of rice farms in Siak District, Riau, Indonesia. Biodiversitas 21: 3797-3804. The research was conducted in Siak District, Riau Province, Indonesia from January to July 2018 in the four subdistricts of rice production centers. The purpose of this study was to identify the ecological conditions of rice farming, analyze the index and ecological sustainability status of lowland rice farming, and analyze the role of each ecological attribute that will have sensitivity to the management of wetland rice in the development of rice farming in the Siak District in the near future. There were 203 sample farmers selected by purposive sampling. Data collection was done by interview and field observation. The sustainability was analyzed using the Rap-Rice method with Multidimensional Scaling (MDS). The results of the Rap-Rice analysis of eight ecological attributes were analyzed; five attributes provided high sensitivity for Sungai Mandau, and three attributes provided high sensitivity for the subdistricts of Bunga Raya, Sabak Auh, and Sungai Apit. Attributes that provided high sensitivity for all subdistricts were attributes of land suitability with land use plans and land conversion rates. The average attributes of ownership of the farm area provided high sensitivity for only three subdistricts (Sabak Auh, Sungai Apit, Sungai Mandau). Based on ecological conditions, analysis of wetland rice farming in Siak District showed a sustainable category for Bunga Raya (56.10\%), Sabak Auh (52.80\%), and Sungai Mandau $(54.90 \%)$ and less sustainability for Sungai Apit $(48.80 \%)$.
\end{abstract}

Keywords: Analysis of sustainability, ecology, farming, lowland rice

\section{INTRODUCTION}

The strategic role of rice is reflected in the large number of workers involved, as it provides employment opportunities and sources of income for more than 25.6 million farmer households, and it has become a part of the national prestige in Indonesia. Rice is also often interpreted as a commodity of political value; for instance, an increase or decrease in the price of rice on the market can trigger demonstrations by certain groups of people that can cause political turmoil (Suryana 2005). Increasing rice production and productivity must always be sought to create food security for the entire community. The national productivity of lowland rice in 2015 was 5,450 tons/ha, with an interval of 2,650-6,210 tons/ha (Ministry of Agriculture 2016). The productivity of rice in Riau, Indonesia averaged 4,007 tons/ha, with an annual amount of 2,667-5,457 tons/ha. Of the 12 municipal districts in Riau Province, Siak District is the district that has the highest rice productivity, at 5,457 tons/ha, with an interval of 4,363-6,596 tons/ha (Department of Agriculture and Animal Husbandry, Riau Province 2016). The rice area in Siak District is spread in four central subdistricts, namely Bunga Raya, Sungai Apit, Sabak Auh, and Sungai Mandau. Five subdistricts that will accommodate the new development of paddy plantations (the potential for making new paddy fields), covering an area of 5,041 ha, are Pusako, Kandis, Tualang, Koto Gasip, and Mempura (Food Crops and Horticulture Service Siak District 2017).
Production of paddy rice in Siak District in 2012-2016 tended to fluctuate; in 2012, rice production was 32,298 tons, increasing to 36,978 tons in 2013 and 40,394 tons in 2014, but decreasing to 30,306 tons in 2015. This decrease was due to the smog disaster that hit Riau Province, including Siak District. In 2016, it increased again to 38,089 tons. Triggers for increasing rice production include increasing the harvest area to $1,396.8$ ha and increasing productivity by 0.023 tons/ha. Until 2016, the four subdistricts of rice centers still provided the largest contribution in the procurement of rice production in Siak District, with a harvest area of 5,515 ha able to contribute 37,361 tons, representing $98.08 \%$ of the production of dry grain in the district. As the first priority, the government's attention to the development and management of rice commodities is significant, especially in the provision of supporting facilities and infrastructure. If such provision is fulfilled, it is expected that increased production and productivity will be achieved by good management, but the data on the management of paddy rice farming in Siak District is still limited, so sustainable farming management models are difficult to form properly. Sustainable agriculture is the implementation of the concept of sustainable development in the agricultural sector, representing farming that can meet current social and economic needs without reducing the ability of future generations to realize their needs. The process of sustainable agricultural production leads to the use of environmentally friendly biological products. If farmers do 
not pay attention to environmental aspects (ecology), then agricultural development will not be declared sustainable. Sustainable agricultural development can take place if these activities are ecologically (planet), economically (profit), and socially (people) sustainable (Serageldin and Steer 1994; Mardikanto 2009).

Ecological sustainability implies that activities must be able to maintain ecosystem integrity, maintain environmental carrying capacity and conserve natural resources; taking into account only 2 Ps (e.g., profit and people) is not enough to realize sustainable development; therefore, the planetary pillar (in this study, ecological management) has an important role in realizing sustainable agricultural development. Seeing the importance of the existence of paddy fields in the four subdistricts for fulfilling rice needs in Siak District, it is necessary to analyze ecological dimensions to form a sustainable rice farming management model. Determination of the sustainability index of wetland rice and any important factors that influence the sustainability of ecological farming needs to be done to evaluate the sustainability of paddy fields so that the problems that hinder the ecological sustainability of paddy fields in Siak District can be addressed quickly and precisely.

The purpose of this study was to identify the ecological conditions of rice farming, assess the level of ecological sustainability of wetland farming, and analyze the role of each ecological attribute that is sensitive to the management of wetland rice farming. This will allow the development of rice farming in Siak District.

\section{MATERIALS AND METHODS}

\section{Study Area}

This research was carried out for seven months, from January to July 2018. It was conducted in the Siak District, Riau Province, Indonesia (Figure 1) and four subdistricts of paddy production-Bunga Raya, Sabak Auh, Sungai Apit, and Sungai Mandau.

\section{Procedures}

The types of data needed in this study consist of primary data and secondary data. Primary data were obtained through direct observation in the field and the results of in-depth interviews with 183 farmers and 20 informal and formal figures as key respondents. Several considerations were adopted in determining the experts to include, following Marimin (2004); these were having competent experience in accordance with the field under study; having a good reputation/position related to their competence in the fields studied; and having high credibility, willingness, and/or in the location studied. The determination of farmer samples was calculated using the Slovin equation in Ryan (2013) with an error margin of $7 \%$. Secondary data were obtained from various sources, such as research reports, scientific research journals, proceedings, research institutions, universities, reports on relevant agencies, and BPS for Siak District in the form of village profiles, monographs, farm census books, and other documents, as well as strategic management plans from each relevant agency.

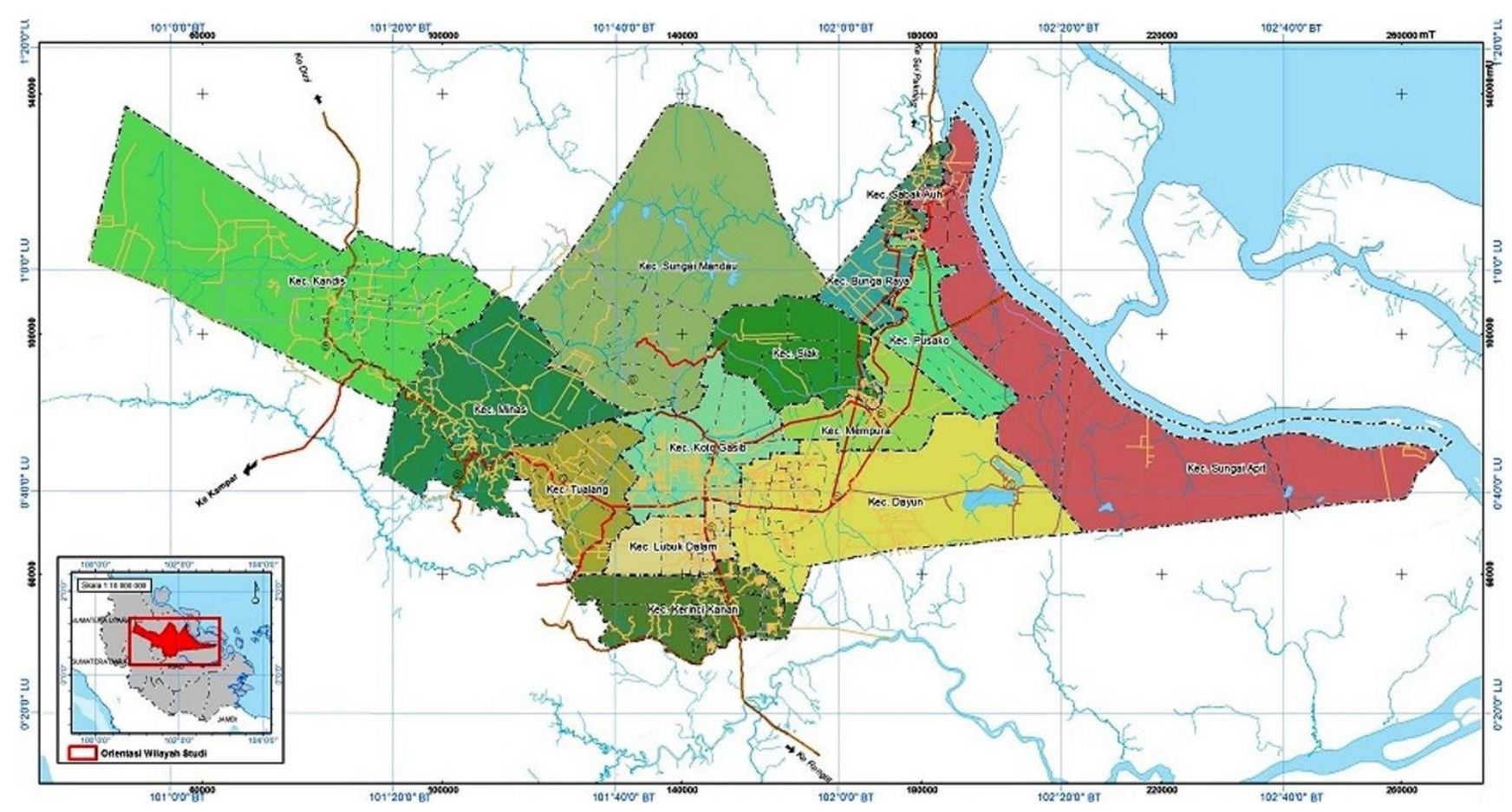

Figure 1. Study area in Siak District, Riau Province, Indonesia 
The status of sustainability of paddy rice farming is expressed in the form of a sustainability index based on the Rap-Rice approach by applying the MDS (multidimensional scaling) technique (Kavanagh 2001; Pitcher and Preikshot 2001). The Rap-Rice approach is modified from the Rapfish (Rapid Assessment Techniques for Fisheries) program developed by the Fisheries Center, University of British Columbia (Fauzi and Anna 2005). The MDS method is a statistical analysis technique that transforms every dimension and multidimensional dimension of sustainability of lowland rice farming (Rao and Rogers 2006). According to Nurmalina (2008), the MDS technique maps two points or the same object as points that are close together, whereas different objects or points are represented by points that are far apart.

\section{Data Analysis}

MDS is a collection of statistical techniques for analyzing similarities and dissimilarities between objects, giving results in the form of plots of dots so that the distance between points represents the degree of similarity or dissimilarity and provides clues to identify unknown variables or factors that influence the appearance of similarities or dissimilarities (Kavanagh 2001; Fisheries 2002). Rap-Rice ordination analysis was carried out in the following stages: (i) determining attributes, (ii) assessment of each attribute in an ordinal (scoring) scale, (iii) analysis of Rap-Rice ordination to determine the ordination and stress values through the ALSCAL algorithm; (iv) rotation to determine the index position and the sustainability status of rice farming management in good and bad ordination; and (v) conducting sensitivity analysis (leverage analysis) and Monte Carlo analysis. Sustainability indicators are tools used to provide information directly or indirectly about the viability of a system in the future from various levels of objectives, where use is considered important because it becomes information for the planning and development of the next system. A stress value $<25 \%$ is considered acceptable.

The method of determining the sustainability index of wetland rice using the Rapfish technique is carried out based on a predetermined systematic approach. According to Nababan and Hermawan (2008), the index and sustainability status can be determined based on the following stages: 1) assessing the attributes of each sustainability dimension and evaluating these attributes based on real data through field observations, expert interviews, and literature studies; 2) scoring attributes of each dimension of sustainability, then analyzing them in the Microsoft Excel program using a template that has been prepared previously, so that a value known as the sustainability index is obtained; and 3) categorizing the sustainability index value based on the sustainability interval to obtain the sustainability status. The intervals for the value of the sustainability score for each dimension are bad (0.00-25.00), low (25.01-50.00), sufficient (50.0175.00), and good (75.01-100.00).

\section{RESULTS AND DISCUSSION}

\section{Ecological Dimension Attributes}

The ecological dimension attributes that were used as parameters in this study were sources of irrigation, land productivity, temperature, and rainfall suitability with commodities.

\section{Source of irrigation}

The source of irrigation for each of the subdistricts studied was from irrigation and rainfall. The utilization of rice fields according to sources of irrigation is shown in Table 1 .

\section{Land productivity}

The Siak District is one of the centers of rice production in Riau Province, and it is the district that has the highest productivity, at 5,457 tons/ha, with an interval of 4,3636,596 tons/ha (Office of Food Crops and Horticulture, Siak District 2016). Data on land productivity for each subdistrict can be seen in Table 2 .

Table 2 shows the highest paddy productivity in Bunga Raya (6,596 tons/ha) and the lowest in Sungai Apit (4,676 tons/ha). Compared with the average productivity of Riau Province, which is only (4,007 tons/ha), productivity in these four subdistricts has been better. This is probably due to the following factors: relatively fertile soil conditions and cultivation technology applied by more advanced farmers; use of superior varieties among most farmers; and management of crops, including fertilization, irrigation, control of plant pest organisms, and weeds, which is mostly in accordance with the needs of plants, especially in Bunga Raya.

Table 1. Utilization of paddy fields according to irrigation sources

\begin{tabular}{lcccc}
\hline \multirow{2}{*}{ Subdistrict } & \multirow{2}{*}{ Land area (ha) } & \multicolumn{2}{c}{ Irrigation } & \multicolumn{2}{c}{ Rainfall } \\
\cline { 3 - 5 } & & Area (ha) & Percentage (\%) & Area (ha) \\
\hline Bunga Raya & 2,252 & 1,802 & 80.02 & 450 \\
Sabak Auh & 1,380 & 639 & 46.30 & 741 \\
Sungai Apit & 823 & 45 & 5.47 & 778 \\
Sungai Mandau & 906 & 594 & 65.56 & 312 \\
Total & 5,361 & 3,080 & 57.45 & 94.70 \\
\hline
\end{tabular}

Source: Food Crops and Horticulture Service Siak District (2017) 
Table 2. Average productivity of lowland rice

\begin{tabular}{lc}
\hline Subdistrict & Productivity (ton/ha) \\
\hline Bunga Raya & 6,596 \\
Sabak Auh & 4,987 \\
Sungai Apit & 4,676 \\
Sungai Mandau & 4,884 \\
\hline Note: Food Crops and Horticulture Service Siak District $(2017)$
\end{tabular}

Table 3. Average rainfall per month (mm) in 2012-2016

\begin{tabular}{llllll}
\hline \multirow{2}{*}{ Subdistrict } & \multicolumn{5}{c}{ Average rainfall per month (mm) } \\
\cline { 2 - 6 } & $\mathbf{2 0 1 2}$ & $\mathbf{2 0 1 3}$ & $\mathbf{2 0 1 4}$ & $\mathbf{2 0 1 5}$ & $\mathbf{2 0 1 6}$ \\
\hline Bunga Raya & 245 & 168 & 232 & 122 & 185 \\
Sabak Auh & 143 & 128 & 134 & 93 & 130 \\
Sungai Apit & 239 & 175 & 142 & 87 & 107 \\
Sungai Mandau & 221 & 86 & 80 & 60 & 138 \\
Jumlah & 848 & 557 & 558 & 363 & 560 \\
Average per month & 212.0 & 139.2 & 147.0 & 90.5 & 140.0 \\
\hline Note: Food Crops and Horticulture Service Siak District (2017)
\end{tabular}

In general, the productivity of rice in the Siak District is quite high, but if it is associated with rice yields in the agro-ecosystem, it still varies between locations and is not optimal. The average yield varies from 4,363 to 6,596 tons/ha, while the results of research on rice production in the Rice Research Center can reach 7-8 tons/ha. Even according to the FAO (2015) report, countries, among others, are caused by low fertilization efficiency, K nutrient deficiency and micro-elements, poor use of seeds; moreover, pest control and weed control are not effective. Furthermore, Isyanto (2012) states that the low productivity of farming is caused by farmers as the main managers having not applied location-specific technology, limited equipment and technology applied, and the limitations of small farmers to use modern inputs (e.g., seeds, artificial fertilizers, and pesticides).

\section{Temperature and rainfall conformity with commodities}

Plant growth and quality, besides being influenced by genetic factors, also depend highly on climate factors, such as temperature and rainfall. In general, the air temperature in Siak District ranges from $25^{\circ} \mathrm{C}$ to $32^{\circ} \mathrm{C}$, while the average rainfall per month for the last five years is presented in Table 3.

Based on Table 3, the highest average rainfall for the last five years occurred in 2012, with an average of 212.0 $\mathrm{mm}$, while the lowest occurred in 2015 , with $90.5 \mathrm{~mm}$. Of the four subdistricts studied, the highest average rainfall was found in Bunga Raya, at $245 \mathrm{~mm}$ in 2012, and the lowest in Sungai Mandau, at $60 \mathrm{~mm}$ in 2015. Rainfall requirements for rice plants to produce well are 125-200 $\mathrm{mm} / \mathrm{month}$ (Anwar et al. 2015). In general, the average rainfall has met the growing requirements for good rice growth, except for Sungai Mandau, which is still below average. However, in 2016, the rainfall in the Mandau River fulfilled the range needed by rice plants. When viewed from the perspective of rainfall requirements, the subdistricts with optimal rainfall for growing rice is Bunga Raya.

Rouw (2008) states that the diversity of rice paddy production in the Merauke region of Papua is strongly influenced by the diversity of rainfall that occurs. The results of the analysis of the average rice production in Merauke for 10 years show that, in the rainy period, the average rice production is higher, at around 4.2 tons/ha, compared with the dry period, when it only reaches 3.2 tons/ha. This result is achieved with an average planting area of 15,000 ha in the rainy season and 5,000 ha in the dry season. The interesting point is that the frequency, dose of fertilizer, and variety used are constant, and this condition implies that there is an influence of the diversity of rainfall inputs on the diversity of results. Furthermore, Latiri et al. (2010) added that rainfall is positively correlated with the yield component. The results of the research he conducted in Tunisia show that the yield component is strongly influenced by the fall in rainfall conditions, which shows the importance of water at the initial growth stage. Water is the main limiting factor in the semi-arid region; this is shown not only in the production per hectare but also in the total harvested area.

\section{Sustainability Index and Status of Management of Rice Paddy Farming in Siak}

Sustainability index of management of wetland rice in Siak

Based on the results of research and interviews with farmers in the Siak District, the index values of all attributes used in the sustainable ecological dimension can be determined as shown in Table 4. Leverage analysis is then carried out to determine the attributes that have sensitivity to ecological sustainability status.

\section{The sustainability status of the ecological dimension}

Attributes that are thought to influence the sustainability of wetland rice management in the ecological dimension are sources of irrigation, soil $\mathrm{pH}$, land productivity, temperature and rainfall suitability, average ownership of farmers' land area, land conversion rate, land suitability with land use plans, and percentage of organic matter content. The results of the ecological dimension (Rap-Rice) sustainability analysis of wetland rice management (Figure 2) returned sustainability index values $>50$ for three subdistricts (Sabak Auh, Sungai Mandau, and Bunga Raya), with a range of values of 52.80-56.10, classifying them into a fairly sustainable category. For the Apit River, the sustainability index value of 48.80 was classified as less sustainable $(<50)$. This value illustrates the condition of rice fields in Sungai Apit under pressure from ecological factors. This is in accordance with the results of research in the field, which illustrates that the Apit River rice field environment has decreased in quality. For example, in the area around the paddy fields, there has been a change in land use to oil palm plantations. This results in a decrease in the level of soil organic matter, lack of water in the dry season, and flooding in the rainy season because the forest around the rice fields has been turned into oil palm plantations. 
Decreasing the quality of land is also influenced by the amount of logging of mangrove forests due to increasingly intensive population activities that result in seawater intrusion, both to the rice fields and the location of residential housing. This results in the occurrence of leveling off (slope of increased productivity), decreasing soil productivity, as well as damage to the balance of the ecosystem and disruption of human health (Andrianto et al. 2015). For this reason, farmers and extension agents need to understand that, to obtain optimum results, besides providing sufficient and balanced fertilizer, the environment also needs to be maintained because the impacts resulting from human activities will affect the structure and function of the ecosystem.

The Rap-Rice analysis, in addition to determining a sustainability index, also produces output in the form of leverage of attributes (leverage attributes). Leverage analysis aims to identify sensitive attributes that influence the sustainability index value of all dimensions. In addition, leverage attributes are attributes that give the highest percentage value in the sustainability of a management dimension.

Based on the analysis of leverage/RMS (root mean square) value (Figure 2), three sensitive attributes were obtained for all subdistricts. Kavanagh and Pitcher (2004) state that the RMS value indicates the magnitude of the role of each attribute in sensitivity to sustainability status. That is, the higher the RMS value, the greater the influence or role of the attributes on sustainability sensitivity.

In Figure 3, the same sensitive attribute is shown for four island conversions and land suitability with land use plans. These two attributes illustrate that the sustainability of lowland rice farming is strongly influenced by changes in the use of paddy fields to other (non-agricultural) uses and the determination of Spatial and Regional Plans (RTRW). According to Widjanarko et al. (2006), the occurrence of changes in land use (land-use change) can be caused by changes in regional spatial plans, the wisdom of development direction, and market mechanisms that do not take sides regarding the sustainability of food selfsufficiency in Siak District. Factors that influence landowners to convert land or sell agricultural land are land prices, proportion of income, land area, land productivity, land status, and policies by the government.

The intensity of land-use change is still difficult to control, and most of the paddy fields that switch functions are precisely the ones with high productivity. The same point is also conveyed by Murniningtyas (2007), who states that the conversion of paddy fields often occurs in technical or semitechnical irrigated rice fields and is located in agricultural areas where the level of application of technology and institutions supporting the development of rice production has advanced. Based on this, a commitment from the Siak District government is needed to continuously protect sustainable food land in the central area of rice production, so that the conversion of paddy fields to other uses does not continue to occur.
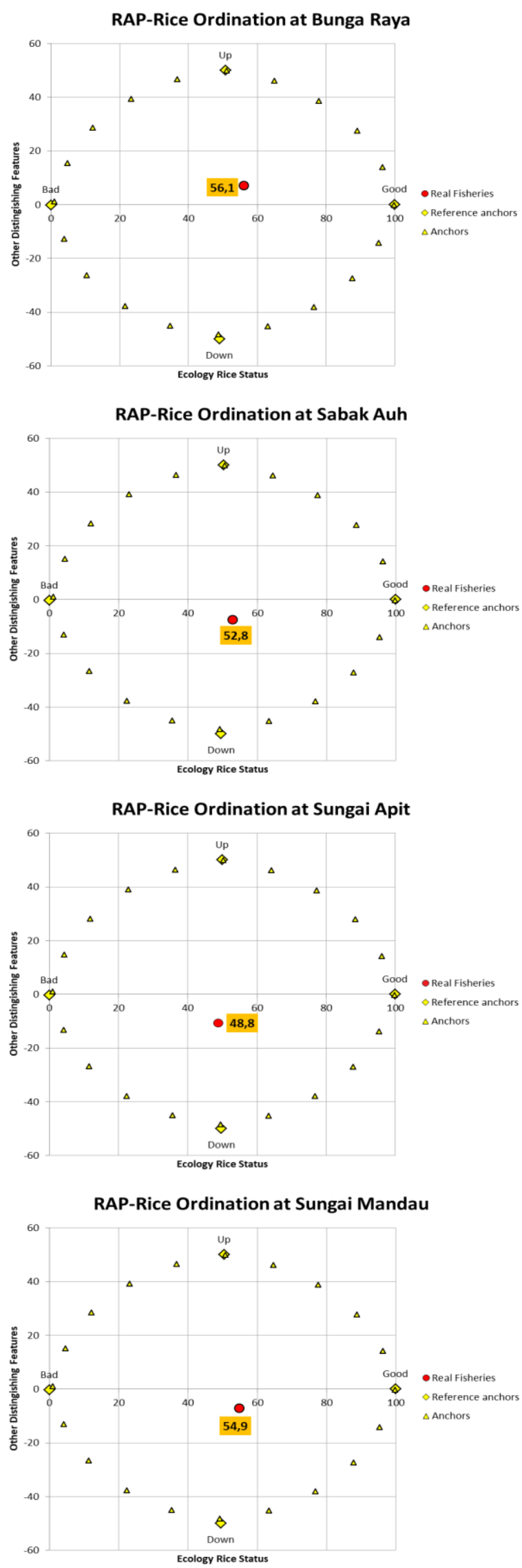

Figure 2. Ecological dimension sustainability index in four subdistricts in the Siak District, Riau, Indonesia 

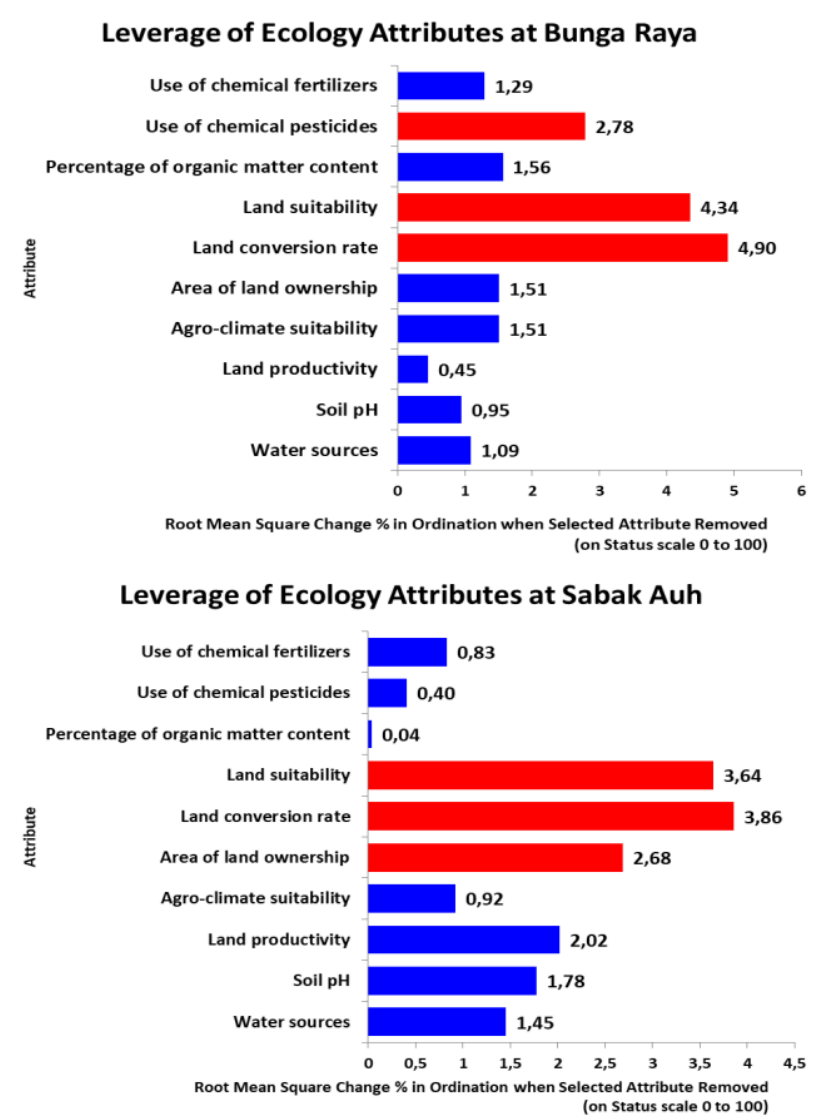

Leverage of Ecology Attributes at Sungai Apit

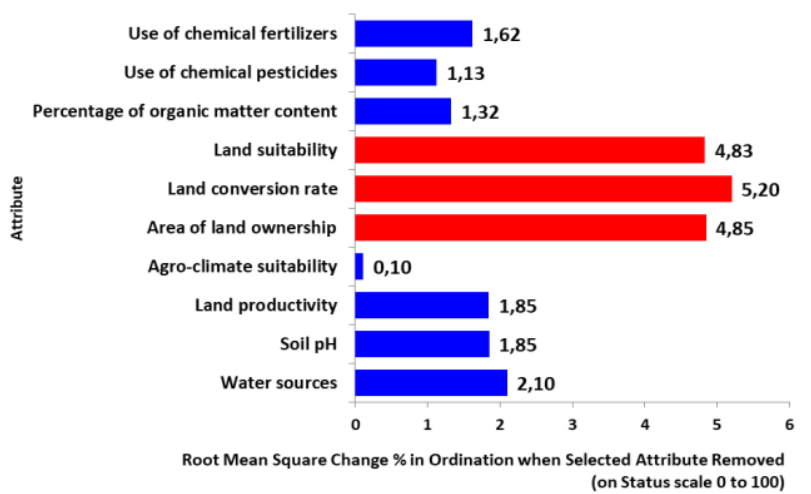

Leverage of Ecology Attributes at Sungai Mandau

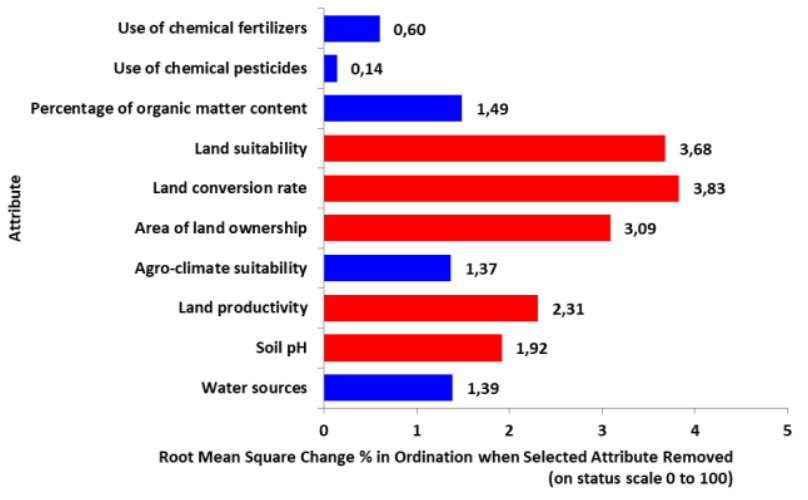

Figure 3. The role of each ecological aspect attribute in four subdistricts in Siak District, Riau, Indonesia is expressed in the form of RMS (root mean square) values
Land suitability describes the level of suitability of a plot of land for a particular use. In the four research subdistricts, if the rice fields are associated with land use plans, they are in accordance with the action plant plan for developing agricultural areas in Siak District. Land suitability assessments are prepared based on land use requirements that cover the growing requirements of the relevant commodities, management, and conservation. The minimum parameters used in land evaluation include slope, air temperature, drainage, texture, organic matter content, soil pH, rainfall, and flood hazards (Djaenudin et al. 2003).

The average attributes of ownership of farmers' land area provide sensitivity for three subdistricts (Sabak Auh, Apit River, and Mandau River). This means that the sustainability of wetland rice farming in these subdistricts is strongly influenced by the area of land owned by farmers. The narrower or smaller the land ownership of farmers, the harder it is for farmers to meet the household needs from their farms, so they need additional income from other sources; in other words, the smaller the land owned by farmers, the more likely they are to leave the business. According to Sudaryanto et al. (2009), the tendency to decrease the area of land ownership will affect the amount of production cultivated and the welfare that will be obtained by farmers, so that the ratio of household income from the agricultural sector to total income also tends to decrease.

The attributes of the use of chemical pesticides are only sensitive to the Bunga Raya. The use of pesticides by farmers is above the recommendation. The reason they do this is to overcome the production reduction caused by the disturbance of pests and diseases. The use of chemical pesticides has proven that these pesticides can rapidly reduce pest populations until attacks can be prevented and crop losses can be reduced. However, if this is done continuously, it will certainly cause an accumulation of residue that exceeds the carrying capacity of the environment; it will not decompose, and instead, it will become a soil poison, such that the soil becomes damaged. Other negative consequences are the emergence of resistance, resurgence of pest explosions secondary to the killing of natural enemies, killing of non-target organisms, and pollution of soil and water. In the end, this will reduce soil productivity, causing damage to the balance of the ecosystem and disruption of human health (Andriyanto 2015). If this is allowed to continue, sustainable agriculture will be difficult to realize. Farmers and extension workers need to understand that, to achieve optimum results, the environment also needs to be maintained because the impacts resulting from human activities influence the ecosystem's structure and function.

\section{Stress value, determination of coefficient, and effects of ecological dimension errors}

The accuracy of the configuration of a point that reflects the original data can be measured by looking at the stress value from the results of Rap-Rice ordinance analysis of each dimension analyzed. Each attribute's ability to explain and contribute to the sustainability of the system is studied by looking at the coefficient value (R2) of each dimension analyzed. The value of stress and the coefficient of determination of the ecological dimension are presented in Table 5. 
Table 4. Values of the ecological dimension scores and attributes of the sustainability of wetland rice management in four subdistricts in the Siak District, Riau, Indonesia

\begin{tabular}{|c|c|c|c|c|c|c|c|}
\hline \multirow{2}{*}{ Attribute } & \multicolumn{2}{|c|}{ Status } & \multirow{2}{*}{ Information } & \multicolumn{4}{|c|}{ Score } \\
\hline & Good & Bad & & BR & SAu & SAp & $\mathbf{S M}$ \\
\hline $\begin{array}{l}\text { Source of irrigation (Ministry of } \\
\text { Agriculture 2016) }\end{array}$ & 4 & 0 & $\begin{array}{l}(0)<20 \% \text { irrigation } \\
(1)>20-40 \% \text { irrigation } \\
(2)>40-60 \% \text { irrigation } \\
(3)>60-80 \% \text { irrigation } \\
(4)>80 \% \text { irrigation }\end{array}$ & 3 & 1 & 0 & 2 \\
\hline $\begin{array}{l}\text { pH in the soil (Soil Research Center } \\
\text { 2015) }\end{array}$ & 3 & 0 & $\begin{array}{l}\text { (0) Very low }<4.5 \\
\text { (1) Low 4.5-5.5 } \\
\text { (2) Medium 5.6-6.5 } \\
\text { (3) High 6.6-7.5 }\end{array}$ & 1 & 1 & 1 & 1 \\
\hline $\begin{array}{l}\text { Land productivity (Department of } \\
\text { Agriculture and Animal Husbandry of } \\
\text { Riau Province 2016) }\end{array}$ & 3 & 0 & $\begin{array}{l}\text { (0) Low } \leq 4 \text { ton } / \mathrm{ha} \\
\text { (1) Medium }>4-5.5 \text { ton } / \mathrm{ha} \\
\text { (2) High }>5.5-7.5 \text { ton } / \mathrm{ha} \\
\text { (3) High }>7.5 \text { ton } / \mathrm{ha}\end{array}$ & 2 & 1 & 1 & 1 \\
\hline $\begin{array}{l}\text { Suitability of agro-climate with } \\
\text { commodities }\end{array}$ & 2 & 0 & $\begin{array}{l}\text { (0) Not in accordance } \\
\text { (1) In accordance } \\
\text { (2) Highly in accordance }\end{array}$ & 1 & 1 & 1 & 1 \\
\hline $\begin{array}{l}\text { Average ownership of farmers' land } \\
\text { area (Food Crops and Horticulture } \\
\text { Service Siak District 2017) }\end{array}$ & 4 & 0 & $\begin{array}{l}(0)<0.5 \text { ha } \\
(1)>0.5-1 \text { ha } \\
(2)>1-1.5 \text { ha } \\
(3)>1.5-2 \text { ha } \\
(4)>2 \text { ha }\end{array}$ & 2 & 1 & 0 & 1 \\
\hline $\begin{array}{l}\text { Land conversion rate (Department of } \\
\text { Agriculture and Animal Husbandry of } \\
\text { Riau Province 2016) }\end{array}$ & 2 & 0 & $\begin{array}{l}\text { (0) High > 3\%/year } \\
\text { (1) Medium 2.5-3\%/year } \\
\text { (2) Low }<2.5 \% / \text { year }\end{array}$ & 2 & 2 & 2 & 2 \\
\hline Land usability with land use plans & 1 & 0 & $\begin{array}{l}\text { (0) Not in accordance } \\
\text { (1) In accordance }\end{array}$ & 1 & 1 & 1 & 1 \\
\hline $\begin{array}{l}\text { Percentage of organic ingredients (Soil } \\
\text { Research Center 2015) }\end{array}$ & 4 & 0 & $\begin{array}{l}\text { (0) Very low }<1 \\
\text { (1) Low }>1-2\end{array}$ & & & & \\
\hline & & & $\begin{array}{l}\text { (2) Medium }>2-3 \\
\text { (3) High }>3-4 \\
\text { (4) Very high }>4\end{array}$ & 2 & 2 & 1 & 3 \\
\hline $\begin{array}{l}\text { Use of chemical fertilizers (Ministry of } \\
\text { Agriculture 2016) }\end{array}$ & & & $\begin{array}{l}\text { (0) Above recommendations } \\
\text { (1) Below recommendations } \\
\text { (2) According to recommendations }\end{array}$ & 0 & 1 & 1 & 1 \\
\hline $\begin{array}{l}\text { Use of chemical fertilizers (Ministry of } \\
\text { Agriculture 2016) }\end{array}$ & 2 & 0 & $\begin{array}{l}\text { Above recommendations } \\
\text { Below recommendations } \\
\text { According to recommendations }\end{array}$ & 0 & 1 & 1 & 1 \\
\hline
\end{tabular}

Note: BR: Bunga Raya; SAu: Sabak Auh; SAp: Sungai Apit; SM: Sungai Mandau

Table 5. Value of stress, coefficient of determination, and effects of ecological dimension errors

\begin{tabular}{lccccc}
\hline Subdistrict & $\begin{array}{c}\text { Sustain- } \\
\text { ability } \\
\text { index } \\
\text { (MDS) }\end{array}$ & Stress & $\mathbf{R}^{2}$ & $\begin{array}{c}\text { Monte } \\
\text { Carlo } \\
\text { analysis* }\end{array}$ & $\begin{array}{c}\text { Difference } \\
\text { (MDS- } \\
\text { MC) }\end{array}$ \\
\hline Bunga Raya & 56.10 & 0.14 & 0.95 & 55.50 & 0.60 \\
Sabak Auh & 52.80 & 0.14 & 0.95 & 52.30 & 0.50 \\
Sungai Apit & 48.80 & 0.14 & 0.95 & 46.70 & 2.10 \\
Sungai Mandau & 54.90 & 0.14 & 0.95 & 54.20 & 0.70 \\
\hline Note: * Error at 95\% confidence level. The index value of 25.01- \\
50.00 is categorized as less sustainable. The index value of 50.01- \\
75.00 is categorized as quite sustainable. Stress value < 0.25 \\
means how well it fits. Values of R2 $>$ 80\%, or close to 100\% \\
contribution, are very good.
\end{tabular}

Table 5 shows that the stress values for the four subdistricts range from 0.14 , and the $\mathrm{R} 2$ value is 0.95 . In
Rapfish the value of stress is said to be good if the value is below 0.25 , meaning that, if the value of goodness of fit in MDS has a stress value close to zero, then the output produced is more similar to the real condition. In other words, the lower the stress value, the better/better the model. Kavanagh (2001) states that the stress value that can be tolerated is $<20 \%$; thus, the model can be well received with a stress value of $14 \%$.

The results of the goodness of fit also show that the ecological sustainability index estimation model can be used, where the value of the squared correlation (R2) is 0.95 or close to 1 . An R-square value approaching 1 means that the data are mapped perfectly. This value illustrates that $95 \%$ of the model can be explained well, and the remaining $5 \%$ is explained by other factors. Kavanagh (2001) states that a value of squared correlation (R2) of more than $80 \%$ indicates that the sustainability index estimation model is good and adequate for use. 
Table 5 also shows that there is no significant difference between the MDS index value and the results of the Monte Carlo analysis, both on the distribution values and the effect of errors at the $95 \%$ level. It can be ascertained that miscalculation of scores, the effect of variations in scores, the stability of the MDS analysis process that is repeated, and errors in input or data loss have no effect. According to Kavanagh and Pitcher (2004), the Monte Carlo analysis can be used as a simulation method to evaluate the impact of random errors in statistical analysis.

The Rap-Rice analysis results are acceptable considering the results of the validation test obtained by the difference in the ecological sustainability index value, with Monte Carlo values of 0.50 to 2.10 , which shows a very small variation in difference (less than 5). This value indicates the error or the impact of the error, giving a relatively low score. This means that the Rap-Rice model for the management of lowland rice is declared to be adequate as an estimator of the sustainability index value. According to Kavanagh and Pitcher (2004), if the value of the Rap-Rice analysis is reduced by a Monte Carlo analysis $>5$, then the results of the analysis are inadequate as estimators of the sustainability index value; moreover, if the difference between the two analysis values is $<5$, then the analysis results are considered sufficient to estimate the sustainability index value.

In conclusion, the ecological conditions of paddy fields in the Siak District, Riau Province, Indonesia is suitable for wetland farming based on the conditions of $\mathrm{pH}$ level of the soil, organic matter content, and availability of irrigation sources, temperature and rainfall conformity with commodities and for land use allocation. The ecological conditions in which the analysis of lowland rice farming in the Siak District show a sustainable category for the Bunga Raya (56.10\%), Sabak Auh (52.80\%), and Sungai Mandau (54.90\%), while Sungai Apit is less sustainable (48.80\%) The ecological attributes that have high sensitivity for the four subdistricts toward the sustainability of future wetland rice farming are land conversion rates and land suitability with land use plans; attributes of average agricultural land ownership are only sensitive to three subdistricts (Sabak Auh, Sungai Apit and Sungai Mandau). Finally, the attributes of chemical pesticide use are only sensitive to Bunga Raya. Ecological sustainability of lowland rice farming in Siak District can be improved by increasing productivity through improving land resources and reducing the rate of conversion.

\section{REFERENCES}

Anwar M, Liu D, Farquharson R, Macadam I, Abadi A, Finlayson J, Wang B, Ramilan T. 2015. Climate change impacts on phenology and yields of five broadacre crops at four climatologically distinct locations in Australia. Agric Sys 132: 133-144. DOI: 10.1016/j.agsy.2014.09.010

Andrianto, Bintoro A, Yuwono SB. 2015. Production and decomposition rate of mangrove (Rhizophora sp) litter leaf in Durian Village and Batu Menyan Village Padang Cermin Subdistrict Pesawan District. Sylva Lestari 3 (1): 9-20. DOI: 10.23960/jsl139-20

Department of Agriculture and Animal Husbandry of Riau Province. 2016. Annual Report. Pekanbaru, Riau. [Indonesian]
Djaenudin D, Marwan H. Subagyo H, Hidayat A. 2003. Technical guidelines for agricultural commodities. Soil Research Center. Center for Land and Agro-climate Research and Development. Bogor. Indonesia. [Indonesian]

FAO. 2015. Statistical Pocketbook World Food and Agriculture. FAO, Rome.

Fauzi A, Anna Z. 2005. Modeling Fisheries and Marine Resources for Policy Analysis. Gramedia, Jakarta. [Indonesian]

Fisheries Centre. 2002. Attributes of Rapfish Analysis for Ecological, Technological, Economic, Social, and Ethical Evaluation Fields. Institute of Social and Ethical Evaluation Fields. Institute of Social and Economic Research Press. St John's, Canada.

Food Crops and Horticulture Service Siak District. 2017. Annual Report. Siak Sri Indrapura, Siak, Riau. [Indonesian]

Isyanto YA. 2012. Influential factors against production in rice farming in Ciamis District. Cakrawala Galuh J 1(8): 1-6.

Kavanagh P. 2001. Rapid Appraisal of Fisheries (RAPFISH) Project. University of British Columbia, Fisheries Centre, Canada.

Kavanagh P, Pitcher TJ. 2004. Implementing Microsoft Excel Software for Rapfish: A. Technique for the Rapid Appraisal of Fisheries Status. University of British Colombia, Fisheries Centre, Canada.

Latiri K, L'homme JP, Annabi M, Setter TL. 2010. Wheat production in Tunisia. Progress. Inter-annual Variability and Relation to Rainfall. Eur J Agron 33: 33-42. DOI: 10.1016/j.eja.2010.02.004.

Mardikanto T. 2009. Agricultural Development. Tri Tunggal Tata Fajar. Surakarta. [Indonesian]

Marimin. 2004. Technique and Application of Decision Making for Multiple Criteria. Grasindo, Jakarta. [Indonesian]

Ministry of Agriculture of the Republic of Indonesia. 2016. Technical Pedestal of Land Optimization Development. Directorate General of Agricultural Infrastructure and Facilities. Jakarta.

Murniningtyas E. 2007. Strategy for Controlling the Function of Agricultural Land. Directorate of Food and Agriculture, Ministry of National Development Planning, Jakarta.

Nababan S, Hermawan. 2008. Overview economic aspect of sustainability small scale fisheries in Tegal district, Central Java. Fish Econ Bul 8(2). http://repository.ipb.ac.id/handle/123456789/43689

Nurmalina. 2008. Analysis of sustainability index and status of rice availability systems in several regions in Indonesia. Agroecon J 26(1): 47-79. DOI: 10.21082/jae.v26n1.2008.47-79.

Pitcher TJ, Preikshot DB. 2001. Rapfish: A Rapid Appraisal Technique to Evaluate the Sustainability Status of Fisheries. Fish Res 49 (3): 255270. DOI: 10.1016/S0165-7836(00)00205-8.

Rao N, Rogers P. 2006. Assessment of Agricultural Sustainability. Curr Sci 91(41): 439-448.

Rouw A. 2008. Analyzing of rainfall variability impact toward rice field production (case study at Merauke Papua). Agric Technol Assess Dev J 11(2): 145-154. DOI: 10.21082/jpptp.v11n2.2008.p\%25p

Ryan T. 2013. Sample Size Determination and Power. John Wiley and Sons, USA. DOI: 10.1002/9781118439241

Serageldin I, Steer A. 1994. Serageldin I, Steer A. 1994. Making Development Sustainable: From Concept to Action Environmentally Sustainable Development Occasional Paper Series No. 2. The World Bank, Washinton D.C

Soil Research Center. 2015. Technical Guidelines for Analysis of Soil Chemistry, Plants, Water and Fertilizers. Soil Research Center. Bogor. [Indonesian]

Suciantini. 2015. Relationship between climate (rainfall) and crop production in Pacitan. Pros Sem Nas Masy Biodiv Indon 1(2): 358365. DOI: 10.13057/psnmbi/m010232. [Indonesian]

Sudaryanto T, Susilowati SH, Sumaryanto. 2009. Small farms: decline or persistence. 111 EAAE-IAAE Seminar, University of Kent, Canterbury, UK.

Sumaryanto. 2009. Small Scale Agriculture Existence in the Era of Global Market Competition. Paper at the National Seminar on "Improving Agribusiness Competitiveness Oriented by Farmers Welfare" organized by the Center for Agricultural Socio-Economic and Policy Studies, IAARD, Ministry of Agriculture on October 14, 2009, Bogor.

Suryana A. 2005. Sustainable Agricultural Development Mainstay of National Development. Seminar on Sustainable Agriculture Systems to Support National Development, February 15, 2005. Sebelas Maret University, Surakarta. [Indonesian]

Widjanarko SW, Moshedayan P, Bambang R, Putu S. 2006. The Agrarian Aspect of Controlling the Conversion of Agricultural (Paddy Field) Lands. Proceedings of the National Seminar on Multifunctional Rice Fields: 19-28. Research and Development Center, National Agrarian Agency. Jakarta. [Indonesian] 
BIODIVERSITAS

Volume 21, Number 8, August 2020

Pages: 3438-3446
ISSN: 1412-033X

E-ISSN: 2085-4722

DOI: 10.13057/biodiv/d210847 